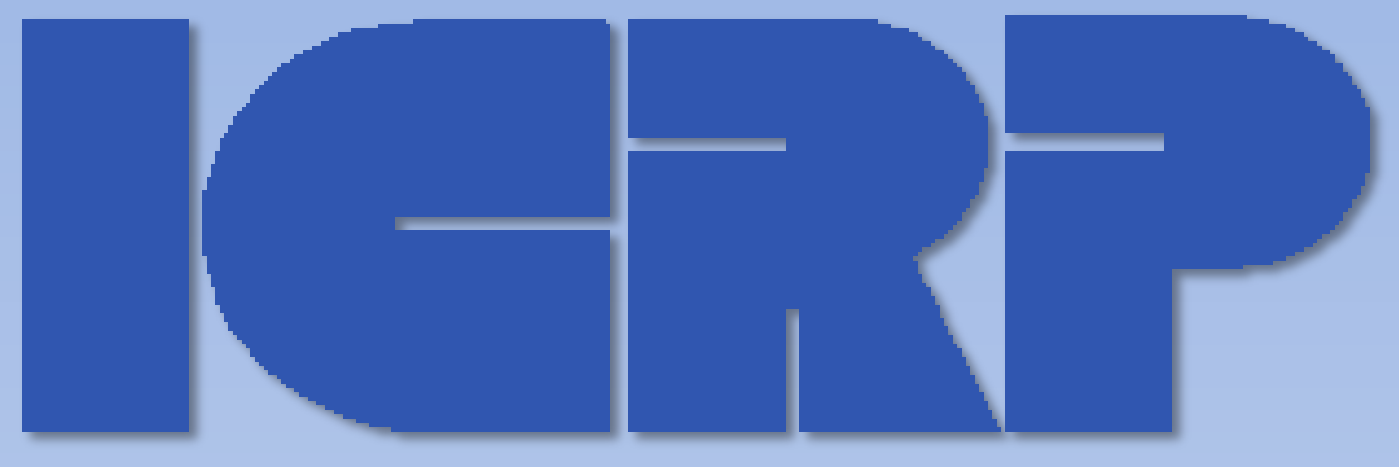

\title{
International Commission on Radiological Protection
}

\section{Annual Report}

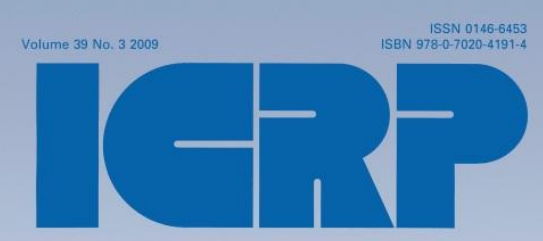

Annals of the ICRP

ICRP Publication 111

Application of the Commission's

Recommendations to the Protection of

People Living in Long-term Contaminated

Areas after a Nuclear Accident or a

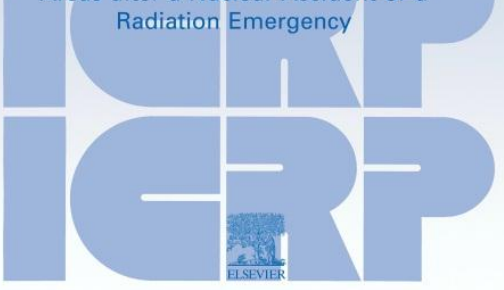

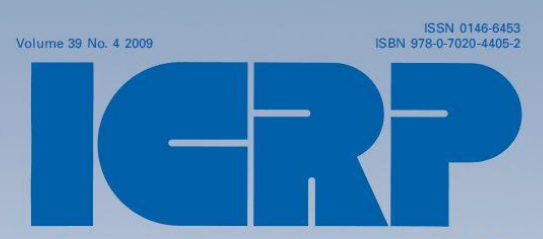

Annals of the ICRP

ICRP Publication 112

Preventing Accidental Exposures from

New External Beam Radiation

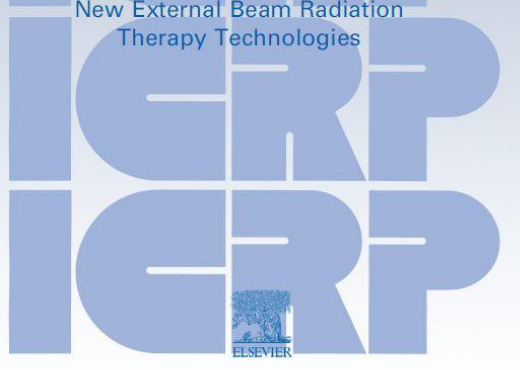

www.icrp.org

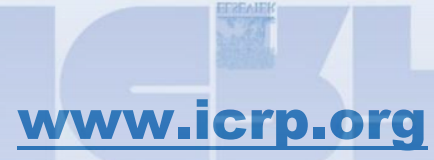

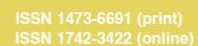

Journal of the ICRU

ICRU REPORT 84

Reference Data for the Validation

of Doses from Cosmic-Radiation

Exposure of Aircraft Crew

OXFORD JOURN IERP 젝음

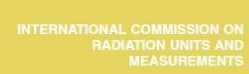


ICRP 2010 Annual Report

ICRP reference 4812-3000-2698

2011-08-09

(C) 2011 ICRP 


\section{Table of Contents}

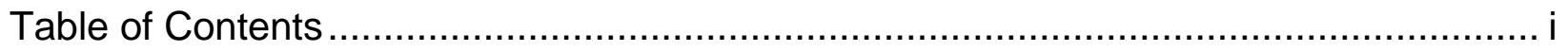

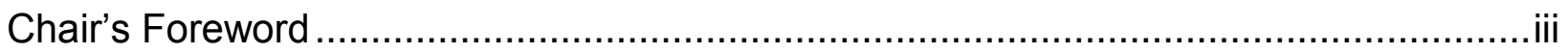

The International Commission on Radiological Protection .......................................... 1

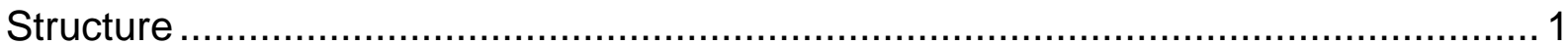

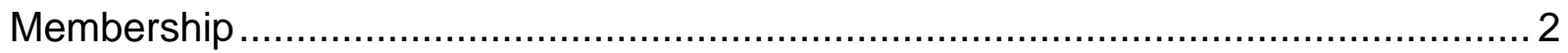

The Work of ICRP

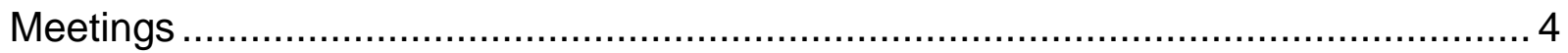

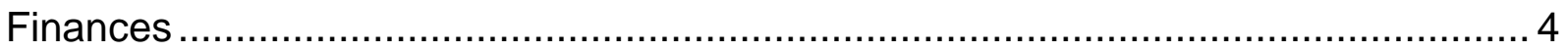

The Work Programme of ICRP and Its Committees ................................................ 5

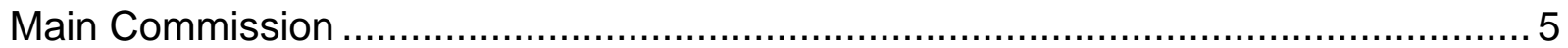

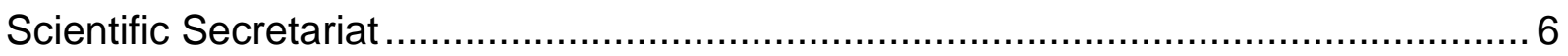

Committee 1 (Radiation Effects) ................................................................. 7

Committee 2 (Doses from Radiation Exposures) ................................................. 10

Committee 3 (Protection in Medicine) .................................................................... 13

Committee 4 (Application of the Commission's Recommendations)......................... 16

Committee 5 (Protection of the Environment) ……............................................ 21

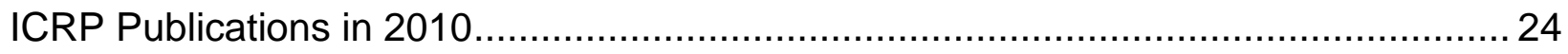

ICRP Publication 111: Application of the Commission's Recommendations to the Protection of People Living in Long-term Contaminated Areas after a Nuclear Accident or a Radiation Emergency................................................................ 24

ICRP Publication 112: Preventing Accidental Exposures from New External Beam

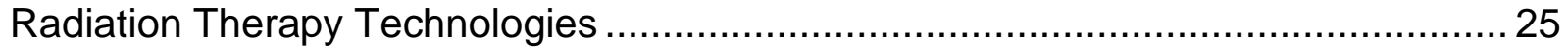

ICRU Report 84 (prepared jointly with ICRP): Reference Data for the Validation of Doses from Cosmic Radiation Exposure of Aircraft Crew....................................... 26

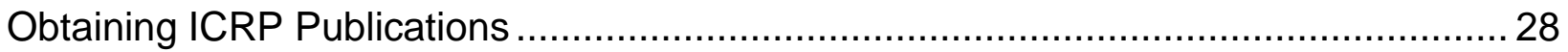

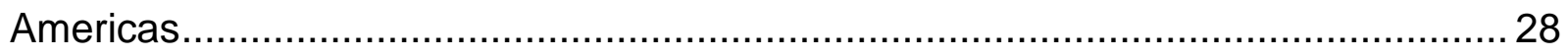

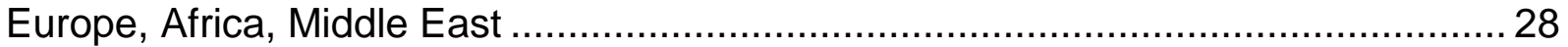

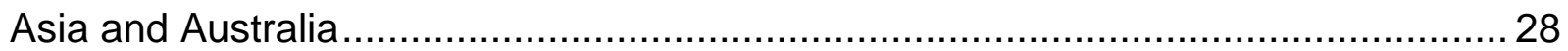

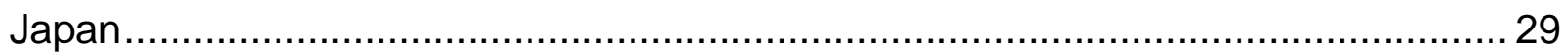

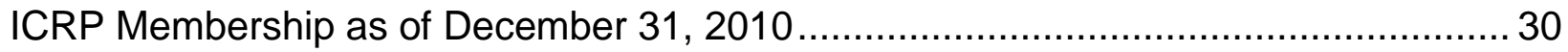




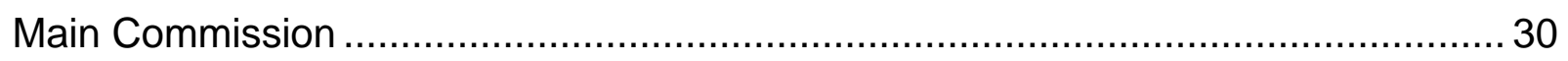

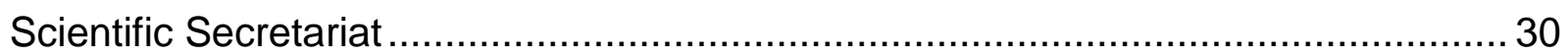

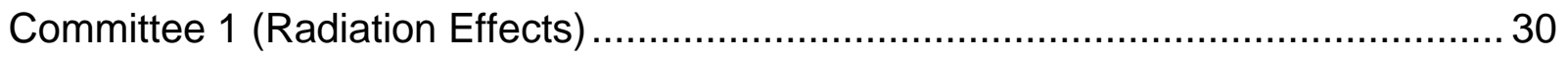

Committee 2 (Doses from Radiation Exposures) ..................................................... 30

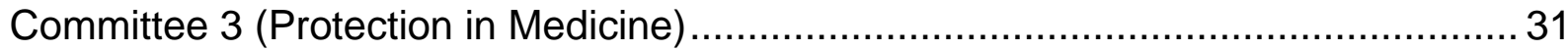

Committee 4 (Application of the Commission's Recommendations).......................... 31

Committee 5 (Protection of the Environment) ......................................................... 31

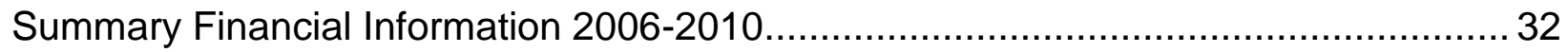

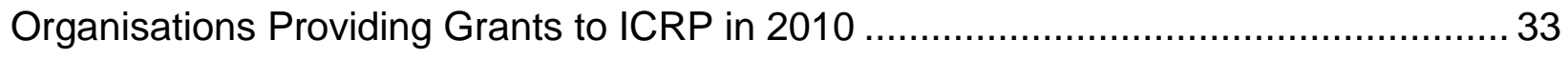

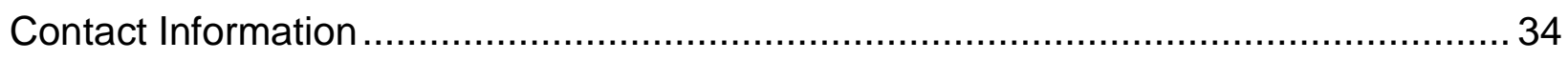




\section{Chair's Foreword}

In 2010, ICRP continued its fundamental work of refining, further elaborating and supporting the System of Radiological Protection based on the firm foundation of ICRP Publication 103, The 2007 Recommendations of Radiological Protection. During the year, the following publications were released: ICRP Publication 111, Application of the Commission's Recommendations to the Protection of People Living in Long-term Contaminated Areas after a Nuclear Accident or Radiological Emergency; ICRP Publication 112, Preventing Accidental Exposures from New External Beam Radiation Therapy Technologies (a follow-up from ICRP

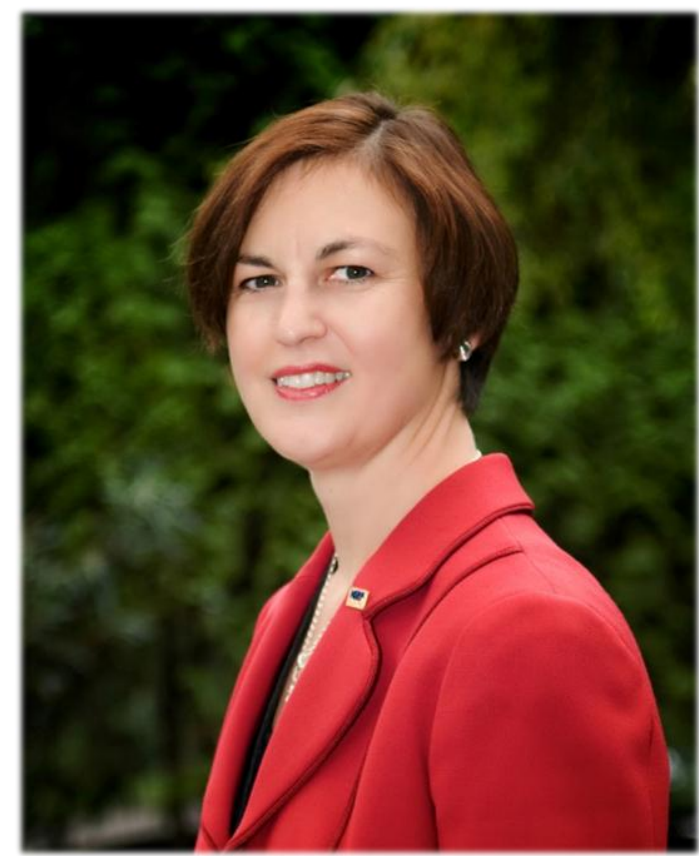
Publication 86 to reflect the advances in modern radiation therapy techniques); and ICRU Report 84 (prepared jointly with ICRP), Reference Data for the Validation of Doses from Cosmic Radiation Exposure of Aircraft Crew. The five ICRP Committees held separate meetings in Europe, North America and Asia, all working through a very busy schedule. There have also been several Task Group meetings and extensive correspondence with significant progress made on many more documents that will be released in the near future.

2010 was also a time of self-examination for ICRP. An internal review of the structure and working methods of ICRP was carried out, with input from both members and observer organisations. This was considered an important contribution with a careful examination of the mandate and how best to achieve objectives. The review should lead to the development of a Strategic Plan in 2011, but some results were clear: ICRP owes much of its success over 83 years to its independent status, scientific rigour, and due attention to conscious value judgements. However, ICRP also recognises that independence does not mean isolation and that now, more than ever, ICRP must continue to work in a transparent manner and in close collaboration with the wide range of organisations that have an interest in radiological protection. ICRP must also continue to attract experts who voluntarily give their time to work for the organisation. These individuals are world-class professionals from a variety of scientific and policy backgrounds, and from a range of cultures. This approach should enable ICRP to maintain its scientific credibility and make value judgements relevant to radiological protection worldwide. These are some of the views that will guide the work of ICRP into 2011 and beyond. 
The Main Commission held two meetings during 2010, the first in Suzhou, China in April and the second in Cape Town, South Africa in November. The Suzhou meeting was nearing completion as the Eyjafjallajökull volcano erupted in Iceland, causing delay and disrupted travel plans for all members travelling west, as for millions of other travellers. Some intrepid and resourceful members arranged circuitous routes home while others remained at the mercy of the airlines. Comparing notes on experiences proved a source of repeated discussion for many weeks to come. Nevertheless, the meeting had been a success with a well-attended one day symposium organised by the Chinese Society of Radiation Protection. Meeting in South Africa in November was designed to strength links in a part of the world where ICRP currently has little interaction. This was achieved, again by one day symposia in Cape Town and Pretoria organised by our hosts, the National Nuclear Regulator with attendance by over 300 participants. These symposia are practical examples of ICRP meeting with communities in order to strengthen dissemination of our recommendations and engage professionals in our work.

This theme will continue in 2011, with a Main Commission meeting and associated symposium in Seoul, Korea. However, the flagship of this endeavour will be the ICRP meeting and symposium to be held in October 2011 in Bethesda, USA. This will be ICRP's first International Symposium on Radiological Protection and will be convened in conjunction with the biennial meeting of the Main Commission and all five standing Committees. The Symposium will include approximately 100 ICRP Main Commission and Committee Members and observers and, in addition, is expected to attract several hundred participants from dozens of countries worldwide. This will be a major milestone in the history of ICRP, and a cornerstone of the efforts to more fully engage everyone with an interest in radiological protection.

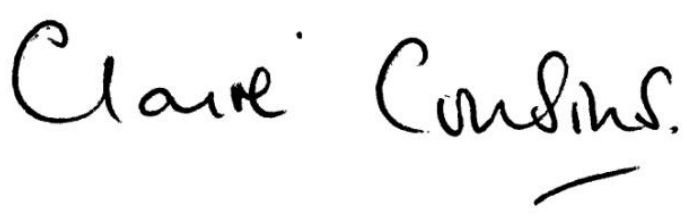

Dr Claire Cousins

ICRP Chair 


\section{The International Commission on Radiological Protection}

The International Commission on Radiological Protection (ICRP) is the primary international body in protection against ionising radiation. ICRP is a registered charity and is thus an independent non-governmental organisation. It was formed in 1928, at the second International Congress of Radiology, as the 'International X-ray and Radium Committee', to advance for the public benefit the science of radiological protection.

ICRP adopted its present name in 1950 to reflect its growing involvement in areas outside that of occupational exposure in medicine, where it originated.

ICRP provides recommendations and guidance on protection against risks associated with exposure to ionising radiation from artificial sources widely used in medicine, general industry and nuclear enterprises, and from naturally occurring sources. These recommendations are published on behalf of the ICRP in the Annals of the ICRP. Each issue provides in-depth coverage of a specific subject area.

\section{Structure}

ICRP comprises the Main Commission, Scientific Secretariat, and five standing committees on: Radiation Effects, Doses from Radiation Exposure, Protection in Medicine, Application of ICRP Recommendations, and Protection of the Environment. Task Groups are established as needed to undertake specific work.

\section{ICRP Main Commission}

\section{Scientific} Secretariat
Committee 1

Effects
Committee2

Doses
Committee 3

Medicine
Committee 4

Application
Committee 5

Environment

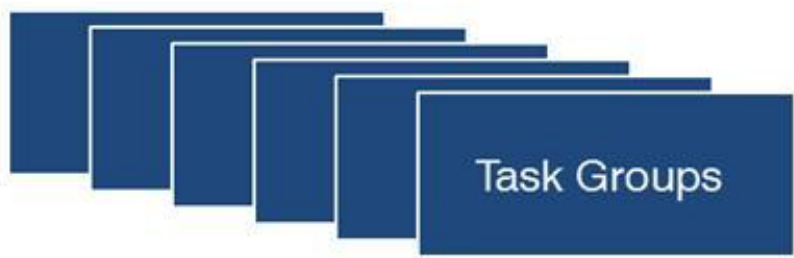

The general structure of ICRP 
The Main Commission and Scientific Secretariat work together to direct, organize, and oversee the work of ICRP. All ICRP reports are approved by the Main Commission prior to publication.

The Committees advise the Main Commission in their area of expertise. They direct the work of Task Groups, and play an important role in ensuring the quality of ICRP reports.

Task Groups are established to undertake a specific task, normally the production of a single ICRP publication, and are generally comprised of a mixture of Committee members and other experts in the field invited to contribute to the work.

Working Parties, less formal than Task Groups, are normally formed of Committee members to explore particular issues, and are sometimes transformed into Task Groups if their work is to result in an ICRP publication.

This multi-tier structure provides a rigorous quality management system of peer review for the production of ICRP publications. Furthermore, before draft ICRP reports are approved for publication, they are regularly circulated to a number of bodies and individual experts, and posted for public consultation through the ICRP web site.

\section{Membership}

All ICRP members are eminent scientists and policy makers in the field of radiological protection. Members of the Main Commission, Committees, Task Groups, and Working Parties are volunteers, most whose employers pay for their time and travel expenses to work with ICRP. Some volunteer their time outside of regular work or after retirement. Members are invited to serve with ICRP based on the skills and knowledge they bring to the work, and as such do not represent their countries or employers when working with ICRP.

The Main Commission, Committees, Task Groups, and Working Parties comprise approximately 250 members from more than 30 countries.

The Commission and its Committees run for four-year terms beginning July 1st. On each occasion of a new term, at least three, and not more than five, members of the Commission must be changed. A similar rate of renewal is sought for the Committees. The current period runs from 2009 July 1 st to 2013 June 30th.

\section{The Work of ICRP}

In preparing its recommendations, ICRP considers the fundamental principles and quantitative bases upon which appropriate radiation protection measures can be established, while leaving to the various national protection bodies the responsibility of 
formulating the specific advice, codes of practice, or regulations that are best suited to the needs of their individual countries.

The primary aim of the Commission's Recommendations is to contribute to an appropriate level of protection for people and the environment against the detrimental effects of radiation exposure without unduly limiting the desirable human actions that may be associated with such exposure.

This aim cannot be achieved solely on the basis of scientific knowledge on radiation exposure and its health effects (the purview of the United Nations Scientific Committee on the Effects of Atomic Radiation, UNSCEAR, and other organisations). It also requires a model for protecting humans and the environment against radiation.

The Recommendations are based on scientific knowledge and on expert judgement. Scientific data, such as those concerning health risks attributable to radiation exposure, are a necessary prerequisite, but philosophical and ethical considerations are similarly necessary, through which societal and economic aspects of protection must be considered. All of those concerned with radiological protection have to make value judgements about the relative importance of different kinds of risk and about the balancing of risks and benefits. In this, radiological protection is no different from other fields concerned with the control of hazards. The Commission believes that the basis for, and distinction between, scientific estimations and value judgements should be made clear whenever possible, so as to increase the transparency, and thus the understanding, of how decisions have been reached.

ICRP has published well over one hundred publications on all aspects of radiological protection. Most address a particular area, but a handful of publications, the so-called fundamental recommendations, describe the overall system of radiological protection. The system of radiological protection is based on the current understanding of the science of radiation exposures and effects, and value judgements. These value judgements take into account societal expectations, ethics, and experience gained in application of the system. As science and societal expectations have evolved over time, so too has the system of radiological protection. The recommendations also continue to take into account novel uses of radiation in medicine and other fields to help ensure an adequate level of protection in all circumstances.

ICRP offers its recommendations to regulatory and advisory agencies and provides advice the intended to be of help to management and professional staff with responsibilities for radiological protection. Legislation in most countries adheres closely to ICRP recommendations. The International Atomic Energy Agency (IAEA) International Basic Safety Standards for Protection against lonizing Radiation and for the Safety of Radiation Sources is based heavily on ICRP recommendations, and the 
International Labour Organisation (ILO) Convention 115, Radiation Protection Convention, General Observation 1992, refers specifically to the recommendations of ICRP. ICRP recommendations form the basis of radiological protection standards, regulations, programmes, and practice worldwide.

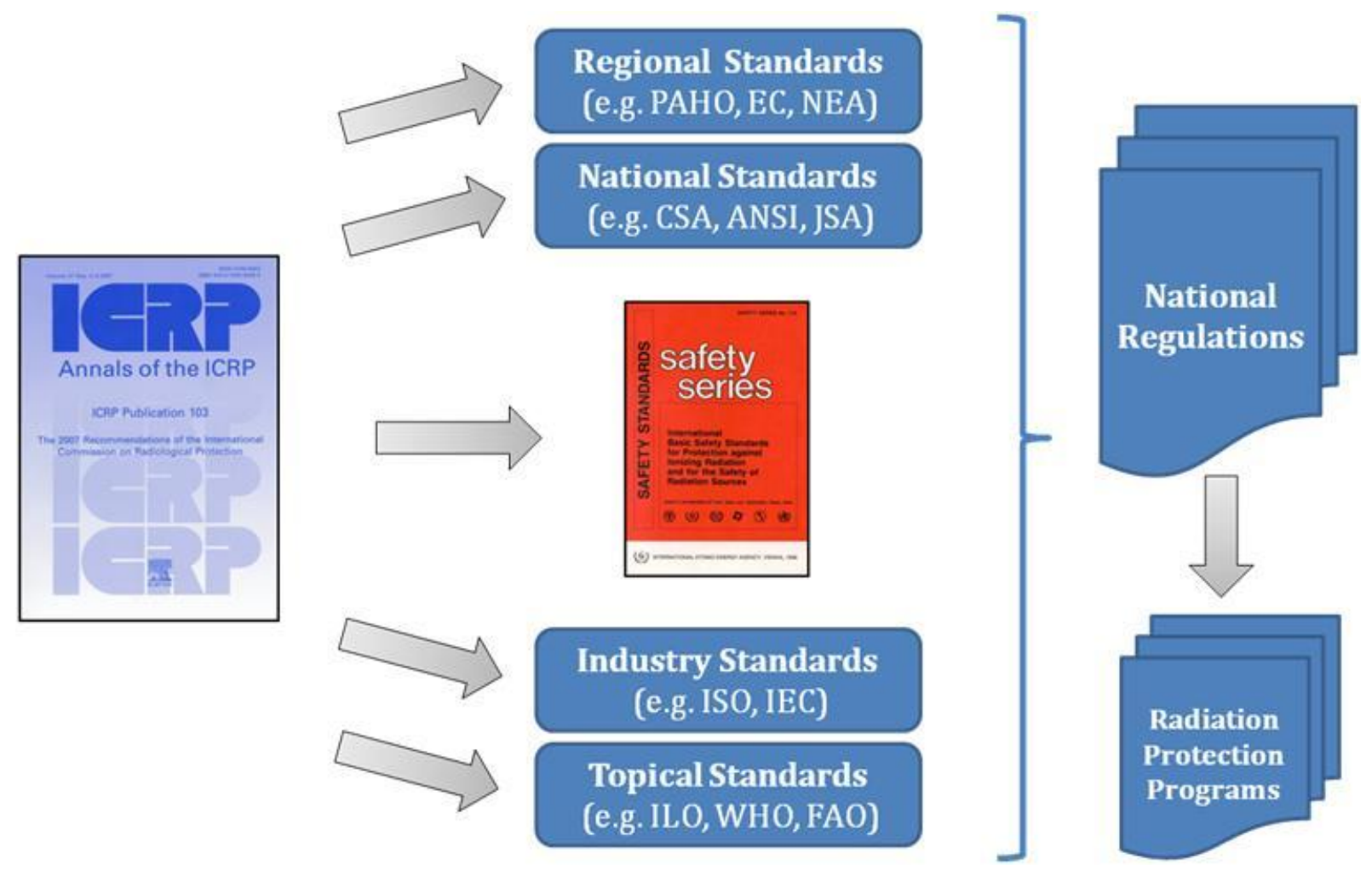

The ICRP System of Radiological Protection forms the basis of radiological protection standards, regulations, programmes and practice world-wide

\section{Meetings}

The Commission normally meets once or twice a year. Each Committee meets once a year. In alternate years an annual meeting of the Commission is normally conducted jointly with all of the Committees. Active Task Groups generally meet annually, while Working Parties tend to meet in conjunction with Committee meetings.

\section{Finances}

The activities of ICRP are financed mainly by voluntary contributions from national and international bodies with an interest in radiological protection. Some additional funds accrue from royalties on ICRP publications. Members' institutions also provide in-kind support to ICRP by making the members' time available without charge and, in many cases, by covering their costs of attending ICRP meetings. 


\section{The Work Programme of ICRP and Its Committees}

\section{Main Commission}

The Main Commission is responsible for management and oversight of all of the work of the Committees, and approval of all ICRP publications. The sections that follow, each focusing on one of the five ICRP Committees, describe this work in detail.

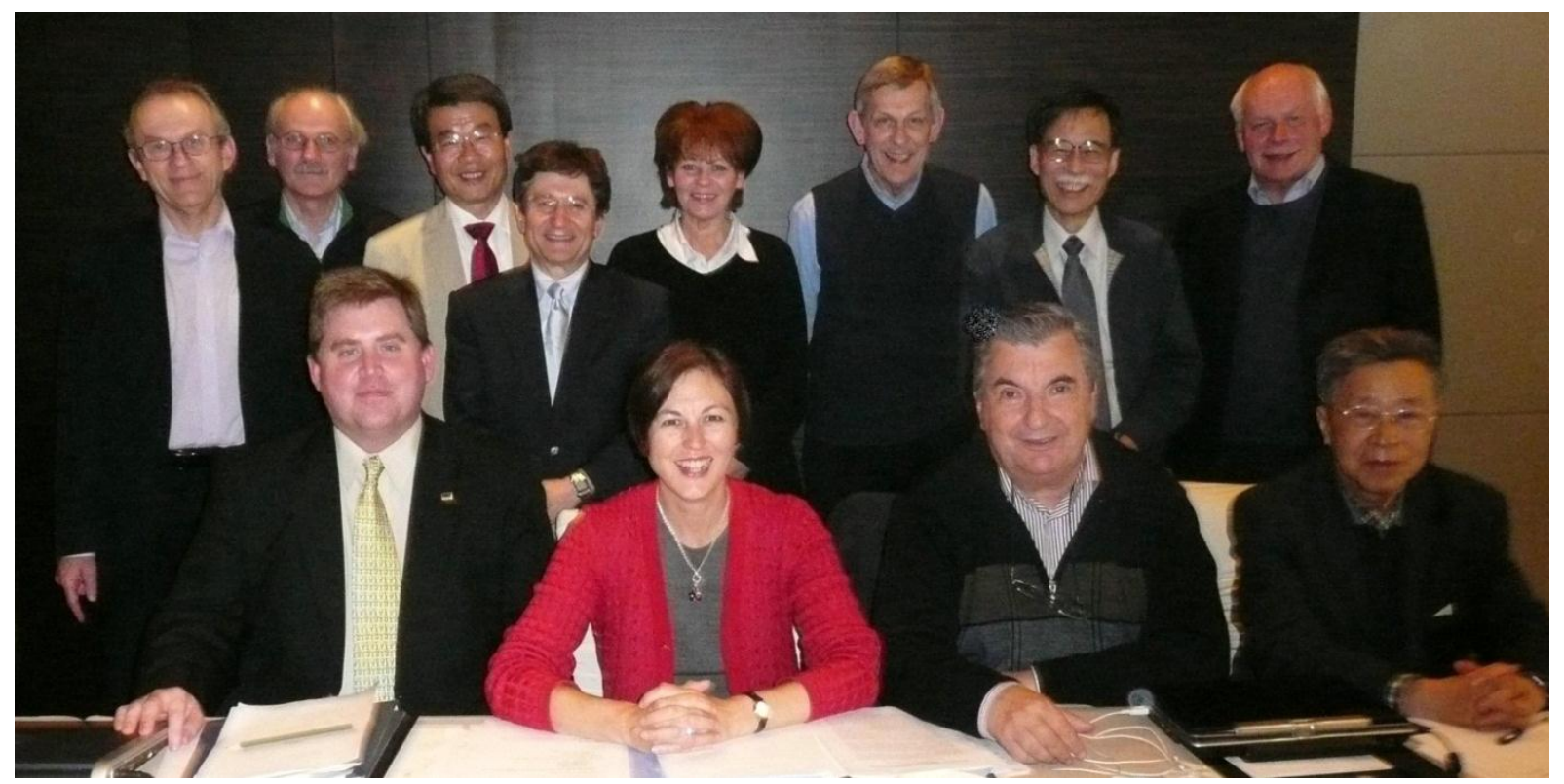

The Main Commission in Suzhou, China, April 2010

Main Commission members and the Scientific Secretary continued to play a key role in the dissemination of information beyond the Annals of the ICRP, through presentations and discussions at many seminars, meetings, conferences, workshops and other forums.

Thus, contact was maintained with the International Atomic Energy Agency (IAEA), the International Commission on Radiation Units and Measurements (ICRU), the International Radiation Protection Association (IRPA), the International Society for Radiology, the OECD Nuclear Energy Agency (OECD-NEA), the United Nations Scientific Committee on the Effects of Atomic Radiation (UNSCEAR), The World Health Organisation (WHO), the International Labour Organisation (ILO), the International Electrotechnical Commission (IEC), and the International Standards Organization (ISO), and many other international, regional, and national organisations. 
ICRP Membership is organised into four-year terms. The current term runs from July 1 , 2009 to June 30, 2013. Dr Claire Cousins, consultant vascular radiologist at Addenbrooke's Hospital, UK, serves as the 12th ICRP Chair since 1928. Dr Cousins is a member of the British Institute of Radiology Radiation Protection Committee and a guest member of the European Society of Radiology Radiation Protection Committee.

\section{Scientific Secretariat}

ICRP operates its Scientific Secretariat in Ottawa, Canada, in an office provided as an in-kind contribution from the Canadian Nuclear Safety Commission. The seat of ICRP remains in the United Kingdom where ICRP is an independent Registered Charity.

Christopher Clement serves as the ICRP Scientific Secretary, the 5th since the position became full-time in 1962 and the 10th since ICRP was first established in 1928. He is assisted by Lynn Lemaire, Executive Assistant.

As ICRP's Chief Executive, Editor of the Annals of the ICRP, and head of the ICRP Scientific Secretariat, the Scientific Secretary oversees the daily operations of ICRP; prepares, organizes, and participates in all Main Commission meetings; is directly involved in aspects of the scientific and policy work of ICRP; often represents ICRP at international meetings; speaks on behalf of ICRP at workshops, symposia, and other forums; responds to requests for information about the work of ICRP; and coordinates the publication of ICRP reports including working with the authors, final editing of the reports, and various discussions and negotiations with the publisher, Elsevier. 


\section{Committee 1 (Radiation Effects)}

Committee 1 has the responsibility for maintaining under review the biological effects of ionising radiation and developing documents that relate such effects to the needs of radiological protection. The members have expertise in epidemiology, statistics, medical sciences, animal sciences, cell and molecular biology, biophysics and genetics. The committee addresses issues of tissue reactions, risks of cancer and heritable diseases including dose responses, effects of dose-rate and radiation quality, effects in the embryo/foetus and genetic factors in radiation response, as well as uncertainties in providing judgements on radiation-induced health effects. The committee advises the Main Commission on the biological basis of radiation-induced health effects and how epidemiological, experimental and theoretical data can be combined to make quantitative judgements on health risks to humans, particularly at low doses, in the form of detriment-adjusted nominal risk coefficients.

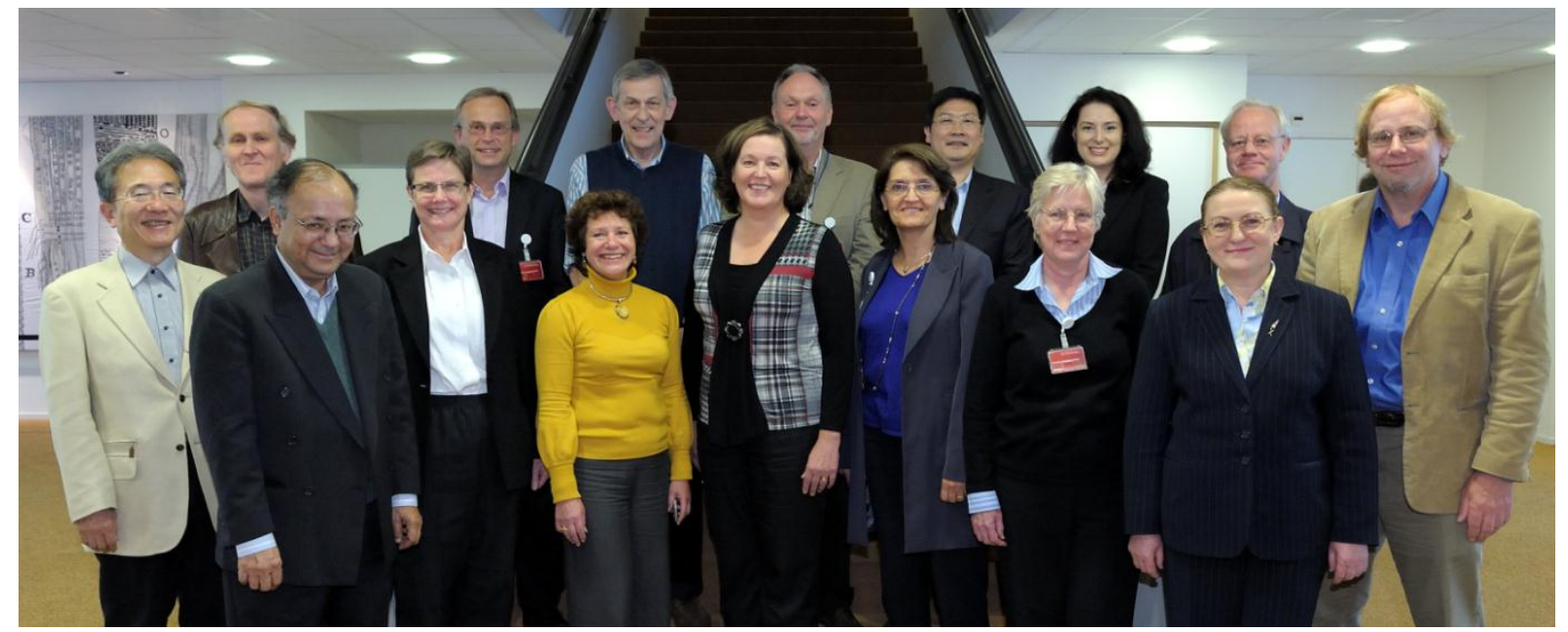

ICRP Committee 1 in Amsterdam, Netherlands, October 2010

Committee 1 considers the approaches used and data input for the estimation of these nominal risks and detriment for stochastic (cancer and heritable effects) and tissue reactions (deterministic) effects that are used for radiation protection standards. In particular, Committee 1 reviews recently published data from radiation epidemiology studies and new data on molecular and cellular effects of ionizing radiations that are pertinent to updating the basis for the 2007 Recommendations found in ICRP Publication 103. This work is undertaken through several Task Groups as described below. 


\section{Task Group 63 on Tissue Reactions and Other Non-cancer Effects of Radiation}

\section{Chair: Fiona Stewart}

This Task Group has revisited the basis and the new data for establishing revised threshold doses for non-cancer effects. The ICRP has not addressed this issue for about 30 years and there are some indications that there is a much greater sensitivity than previously thought for some tissues (e.g., lens of the eye) that must be considered. This will be a comprehensive review of all major organ systems considering both acute and chronic exposures for a variety of exposure scenarios.

\section{Task Group 64: Alpha Emitters}

\section{Chair: Margot Tirmarche}

This Task Group has reviewed the recent reports on epidemiological data pertaining to lung cancer risk for uranium miners and residential radon exposed populations and has developed a revised detriment-adjusted nominal risk coefficient. A report of the Task Group on lung cancer and radon has been created. The Task Group is now considering the cancer risks for alpha emitters other than radon.

\section{Task Group 75: Stem Cell Radiobiology}

\section{Chair: Ohtsura Niwa}

This Task Group was established in 2007 to review the current state of knowledge of stem cell biology and radiobiology and the potential impact of stem cell effects on radiation cancer risks. There has been an enormous increase in knowledge of stem cell biology in the past 3-5 years although much less on radiation effects. The Task Group is reviewing the literature on stem cell radiobiology in relation to cancer risk estimation and to establish how knowledge of stem cell response can address uncertainties in risk estimation. A comprehensive report that considers stem cells in a range of organs and tissues is in draft form and will be completed within the next year.

\section{Working Party on DDREF}

\section{Chair: Julian Preston}

This Working Party has continued its development of a short report on the assessment of DDREF with an emphasis on the selection of data used to support the estimation of DDREF and the specific model used for its estimation, with an emphasis on Bayesian models. The discussions have been led by Dale Preston following the untimely death of Elaine Ron who had chaired the Working Party. The discussions have been facilitated by use of an extensive review that was developed by SENES Consultants for NIOSH. A draft report has been developed and is undergoing review and revision. It is anticipated that the effort will be completed during the 4th quarter of 2011. 


\section{Other Review Activities}

Committee 1 continues to review the recent literature on a number of topics related to the 2007 Recommendations in ICRP Publication 103.

- Radiation epidemiology

- Tissue reactions and non-cancer effects

- Susceptible populations

- Dosimetry and exposure

- Radiobiology

- Heritable effects

- Epigenetics

- DNA Repair and non-targeted effects 


\section{Committee 2 (Doses from Radiation Exposures)}

Committee 2 is concerned with the development of dose coefficients for the assessment of internal and external radiation exposure of workers and members of the public, considering different situations of exposure. This work involves the development of reference biokinetic and dosimetric models, reference anatomical models of the human body, and reference anatomical and physiological data.

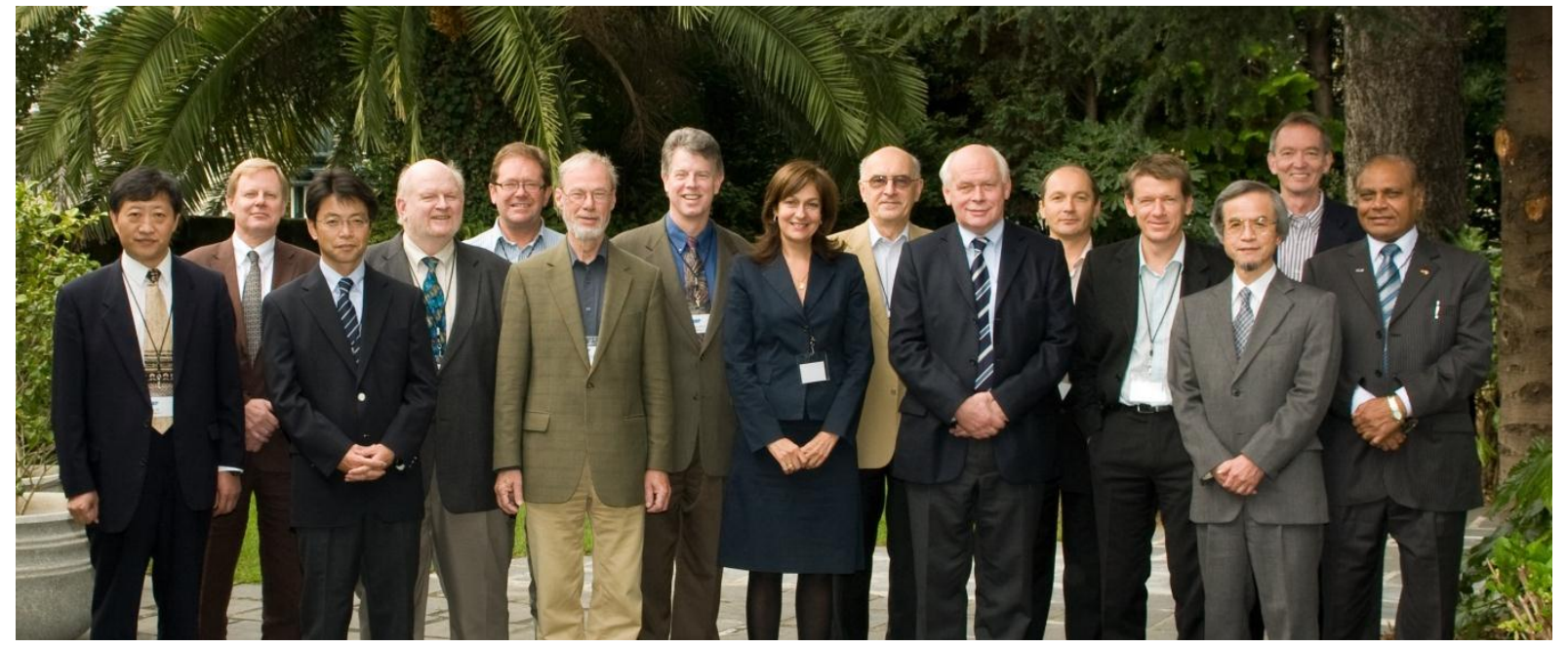

ICRP Committee 2 in Porto, Portugal, November 2009

Following from the 2007 Recommendations, Committee 2 and its Task Groups are engaged in a substantial programme of work to provide new dose coefficients for various circumstances of radiation exposure. The Committee works closely with the International Commission on Radiation Units and Measurements (ICRU) and will issue joint reports as appropriate. The Committee will lead on considerations of the use of the protection quantities, equivalent and effective dose, and proposals for alternatives where assessments of individual risk are required. Committee members support the work of the other ICRP Committees, providing members for Task Groups of Committees 1,3 and 5.

\section{Task Group 2: Internal Dosimetry (INDOS)}

\section{Chair: François Paquet}

The primary purpose of the ICRP Committee 2 Task Group on Internal Dosimetry (INDOS) is to develop biokinetic models for the behaviour of inhaled and ingested radionuclides. Biokinetic models for individual elements and their radioisotopes are used to calculate the total number of radioactive decays (transformations) occurring within specific tissues, organs or body regions (source regions) during a given period of time (usually to age 70). Dosimetric models are then used to calculate the deposition of 
energy in all important organs/tissues (targets) for emissions in each source region, and hence absorbed, equivalent and effective dose. All dose coefficients require revision following the changes made in the 2007 Recommendations. In addition to the changes in dosimetry discussed above, the opportunity is being taken to update biokinetic models for the new calculations. Doses will be calculated using the ICRP Publication 100 Human Alimentary Tract Model and changes will be made to the ICRP Human Respiratory Tract Model to take account of more recent data. In addition, revisions are being made to many models for the systemic behaviour of individual elements following absorption to blood, making them more physiologically realistic. Work continues on a series of reports to replace ICRP Publications 30 and 68 on doses to workers. These reports will provide data for the interpretation of bioassay measurements as well as giving dose coefficients. Attention will then be focussed on dose to members of the public.

\section{Task Group 4: Dose Calculations (DOCAL)}

\section{Chair: Professor Wesley Bolch}

DOCAL is responsible for developing methods, computational models, and associated reference data for the calculation of absorbed, equivalent, and effective doses from both external and internal sources of radiation. Following the modifications of tissue and radiation weighting factors in ICRP Publication 103 and the release of ICRP Publication 110 Adult Reference Computational Phantoms, a major focus of DOCAL activities this past year was to assemble new reference data on external radiation dose coefficients using the revised values of the weighting factors and the ICRP adult reference computational phantoms. A subset of these data has been provided to a joint ICRP/ICRU Task Group of on radiation doses to aircraft crew and DOCAL also provided calculational support to the Task Group on Radiation Protection in Space. Progress is being made on improving skeletal dosimetry using paired macro- and micro-CT images to define dose delivery within target regions of red bone marrow and bone endosteum. DOCAL continues to develop paediatric phantoms for use by Committees 2 and 3 in dose assessments for both environmental and medical exposures. The Task Group is working closely with the Task Group on Internal Dosimetry (INDOS) on the generation of dose coefficients for the upcoming Occupational Intakes of Radionuclides (OIR) report.

\section{Task Group 67: Radiation Exposures of Astronauts in Space}

\section{Chair: Günther Dietze}

This Task Group is concerned with the exposure of astronauts on space missions. The complex radiation fields in space include very high-energy charged particles with many different heavy ions up to nickel-59 from cosmic radiation together with secondary 
particles produced by nuclear reactions in the materials of space vehicles. These fields are very different from radiation fields on earth. The report will focus on providing data on the radiation fields, for the assessment of doses to astronauts and will describe methods of radiation monitoring, of measuring radiation field parameters, and of individual monitoring of astronauts. The absorbed dose coefficients for organs and tissues of the human body used in the report are being calculated using the new ICRP reference anatomical models, in cooperation with the DOCAL Task Group.

\section{Task Group 79: The Use of Effective Dose}

\section{Chair: John Harrison}

This Task Group will produce a report to provide guidance on when the quantity 'effective dose' can be used and when it should not. Experience has shown that the quantity 'effective dose' which has been defined and introduced by ICRP for risk management purposes, i.e. for risk limitation and optimization, is widely used in radiological protection and related fields beyond its original purpose, incorrectly in some cases. Useful guidance on restrictions on the use of the quantity is provided by Committee 2 in annex B to the main recommendations. This guidance needs to be further expanded, and proposals made for the control of exposures and risk management in situations where 'effective dose' should not be used. Specific advice on the use of dose coefficients may also be given.

An important focus of the report will be medical exposures. The use of 'effective dose' for patient exposures is problematic particularly when it is used to assess risk in specific individuals, including children. However, effective dose may be a useful tool for comparisons of, for example, different diagnostic examinations and interventional procedures, the use of different technologies for the same medical examinations, and the use of similar technologies and procedures in different hospitals and countries. 


\section{Committee 3 (Protection in Medicine)}

Committee 3 is concerned with protection of persons and unborn children when ionising radiation is used for medical diagnosis, therapy, or for biomedical research; also, assessment of the medical consequences of accidental exposures.

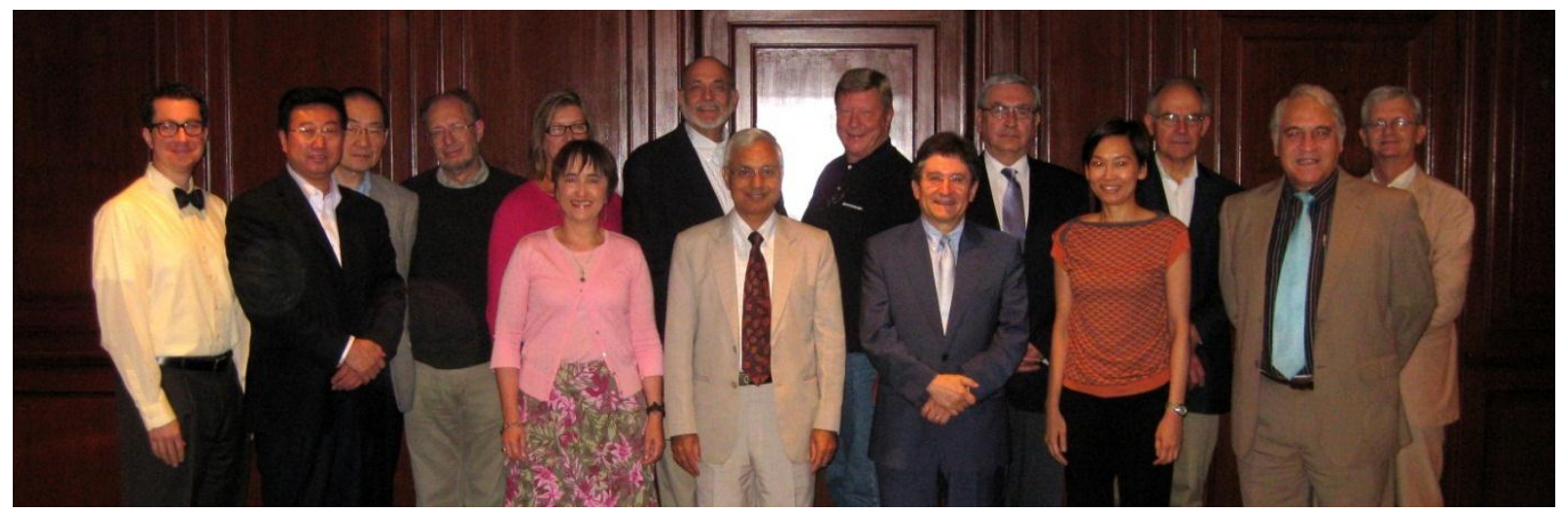

ICRP Committee 3 in Hong Kong, China, October 2010

Committee 3 evaluates aspects of radiological protection relevant to medicine with ongoing Task Groups and Working Parties as described below.

Donald Miller and Lawrence Dauer became members of Committee 3 in 2010.

ICRP Publication 112 on Preventing Accidental Exposures from New External Beam Radiation Therapy Technologies was published in 2010. Educational material containing power point slides in English and Spanish was provided on ICRP website.

\section{Task Group 36: Doses to Patients from Radiopharmaceuticals}

\section{Chair: Sören Mattsson}

Dose coefficients for the new computational phantoms for adults and children from DOCAL are being completed. A number of options were discussed for dissemination of material. These included making free use via the ICRP website of a newly developed viewer for indexing the document available on the ICRP website with provision to allow a subscription to use a viewer for indexing and retrieval of available information. It is assumed that the user will have access to the documents via subscription from Elsevier or via local libraries. Committee 3 approved the biokinetic models for 18F-FLT, -FET and-choline. 


\section{Task Group 62: Patient and Staff Radiological Protection in Cardiology}

\section{Chair: Donald Miller}

A draft document prepared by this Task Group initially chaired by Claire Cousins was further developed under the chairmanship of Donald Miller. The report includes a new chapter on principles of radiological protection and revisions of other chapters. Development of this document was completed in 2010 with the aim of public consultation followed by publication in late 2011 .

\section{Task Group 70: Secondary Cancer Risk in Modern Radiotherapy: Practical} Recommendations

\section{Chair: Jean-Marc Cosset}

The report of this Task Groups is being prepared in collaboration with the International Commission on Radiological Units and Measurements (ICRU). It describes a variety of risk models with respect to secondary cancer in modern radiotherapy.

\section{Task Group 78: Radiological Protection outside the Imaging Department in} Fluoroscopically and Radio-isotopically Guided Procedures

\section{Chair: Madan Rehani}

This document covers radiological protection of patients and staff in procedures performed outside the imaging departments by clinical specialists such as orthopaedic surgeons, urologists, vascular surgeons, gastroenterologists and others. Development of this document was completed in 2010 with the aim of public consultation followed by publication in late 2011.

Working Party on Education and Training in Radiological Protection for Diagnostic and Interventional Procedures

\section{Chair: Eliseo Vano}

Public consultation on this document being developed by this Working Party resulted in about 300 comments from 19 individuals and 15 organizations or societies. These comments were addressed and the document approved for publication. It should be available in early 2011.

Working Party on Radiological Protection in Paediatric Diagnostic and Interventional Radiology

\section{Chair: Pek-Lan Khong}

This Working Party was previously chaired by Professor Hans Ringertz. Development of the report on radiological protection in paediatric diagnostic and interventional radiology 
was completed in 2010 with the aim of public consultation followed by publication in late 2011.

Working Party on Radiological Protection in Ion Beam Therapy

\section{Chair: Yoshiharu Yonekura}

This Working Party revised the title of their report to refer to ion beam therapy rather than charged particle therapy or proton and heavier particle therapy. A final draft of this report is expected in 2011, with publication likely in 2012

Working Party on the Use of lonising Radiation in Imaging of the Asymptomatic Individual

\section{Chair: Katrine Ahlstrom Riklund}

There was considerable discussion on the topic given the lack of evidence available and difficulties in providing concrete comments on justification. It was felt that the focus should therefore be on the process of and framework for justification rather than providing specific advice or recommendations on justification. The Working Party decided that a short document of a few pages be prepared in the coming months and circulated for comments within Committee 3.

Working Party on Follow up of Persons Accidentally Exposed

\section{Chair: Igor Gusev}

The efforts of this Working Party were deferred to next year.

\section{Future topics:}

- Occupational protection in brachytherapy, priority 1. Lawrence Dauer (Chair).

- Justification: Framework on justification on the use of ionizing radiation in medical imaging: Priority 1. Hans Ringertz (Chair).

- Occupational protection issue in relatively higher exposure situations in interventional procedures. Awaiting advances and results from the IAEA in ISEMIR project. Priority 2. Pedro Ortiz-Lopez (Chair).

- Radiation protection in cone-beam CT (medical and dental). Priority 1 - Madan Rehani (Chair).

- Review existing documents by the IAEA and others on occupational protection issues in PET/CT and cyclotron use; decide action. Priority 2- Soren Mattson and Lawrence Dauer to keep under review. 
- Extending the use of reference levels to interventional radiology, digital radiology and new technology, priority 2. - wait.

\section{Committee 4 (Application of the Commission's Recommendations)}

ICRP Committee 4 has the responsibility to develop principles, recommendations and guidance on the protection of man against radiation exposure and to consider their practical application in the various exposure situations. The Committee also acts as a major point of contact between the ICRP structure and other international organisations and professional bodies concerned with protection against ionising radiation.

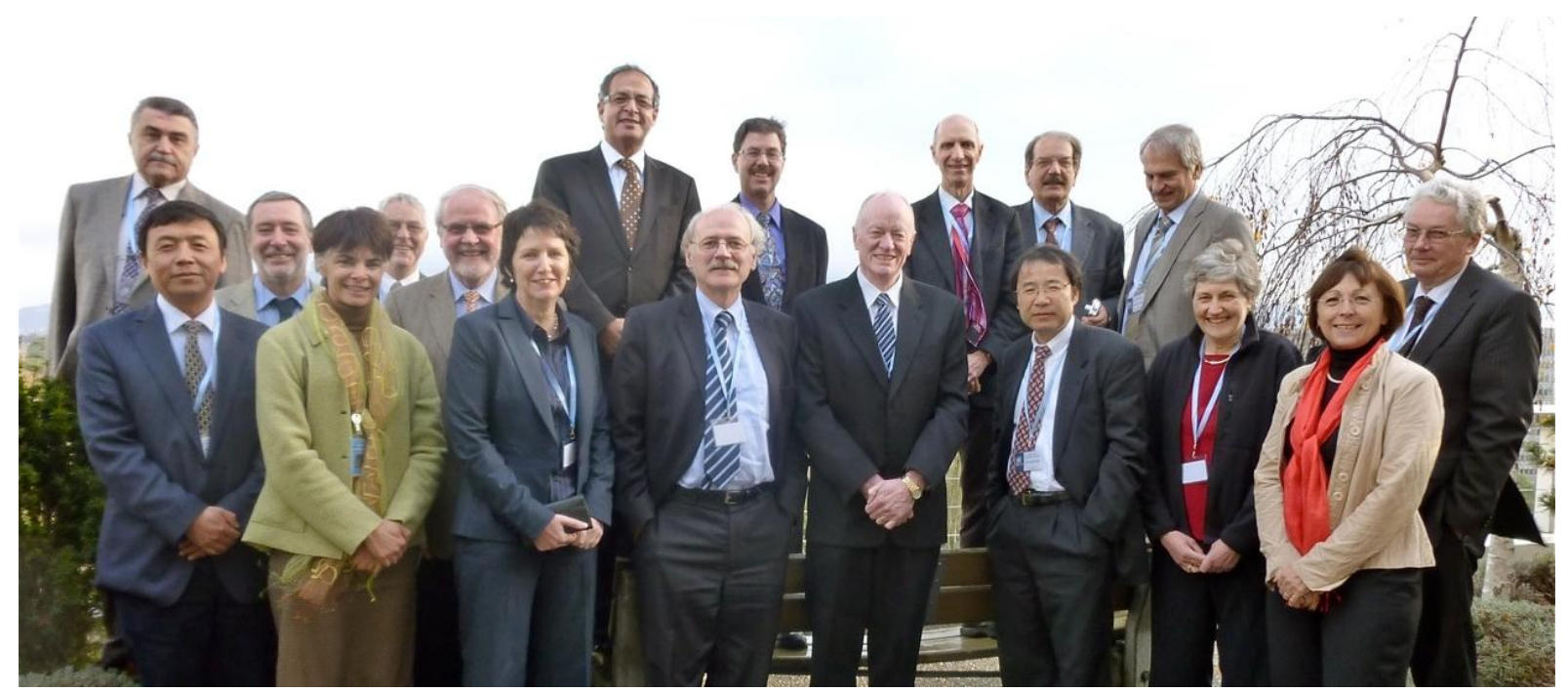

ICRP Committee 4 in Geneva, Switzerland, November 2010

During the current 4-year term the work of Committee 4 is structured according three priorities:

- To develop advice on the implementation of the new recommendations (ICRP Publication 103) and to contribute to their dissemination: review and update past publications, recommendations for the application of the radiological protection principles in particular exposure situations;

- To review the ethical and social values underlying the principles and concepts of the radiation protection system: precautionary principle, tolerability of risk, equity, sustainable development...

- To enhance the dialogue and cooperation with international organisations and professional societies. 
In 2010 Committee 4 met in Geneva, Switzerland, November 15 to 19, hosted by the World Health Organization (WHO) an official observer organisation to ICRP Committees.

In addition to reviewing its current programme of work including several draft reports under preparation the Committee further clarified how the basic radiation protection principles and the dose criteria apply to the protection of the public and workers according to the three exposure situations defined in ICRP Publication 103, i.e. planned, existing and emergency exposure situations. The Committee also considered working mechanisms to improve in practice its cooperation with the international and professional organisations involved as observers.

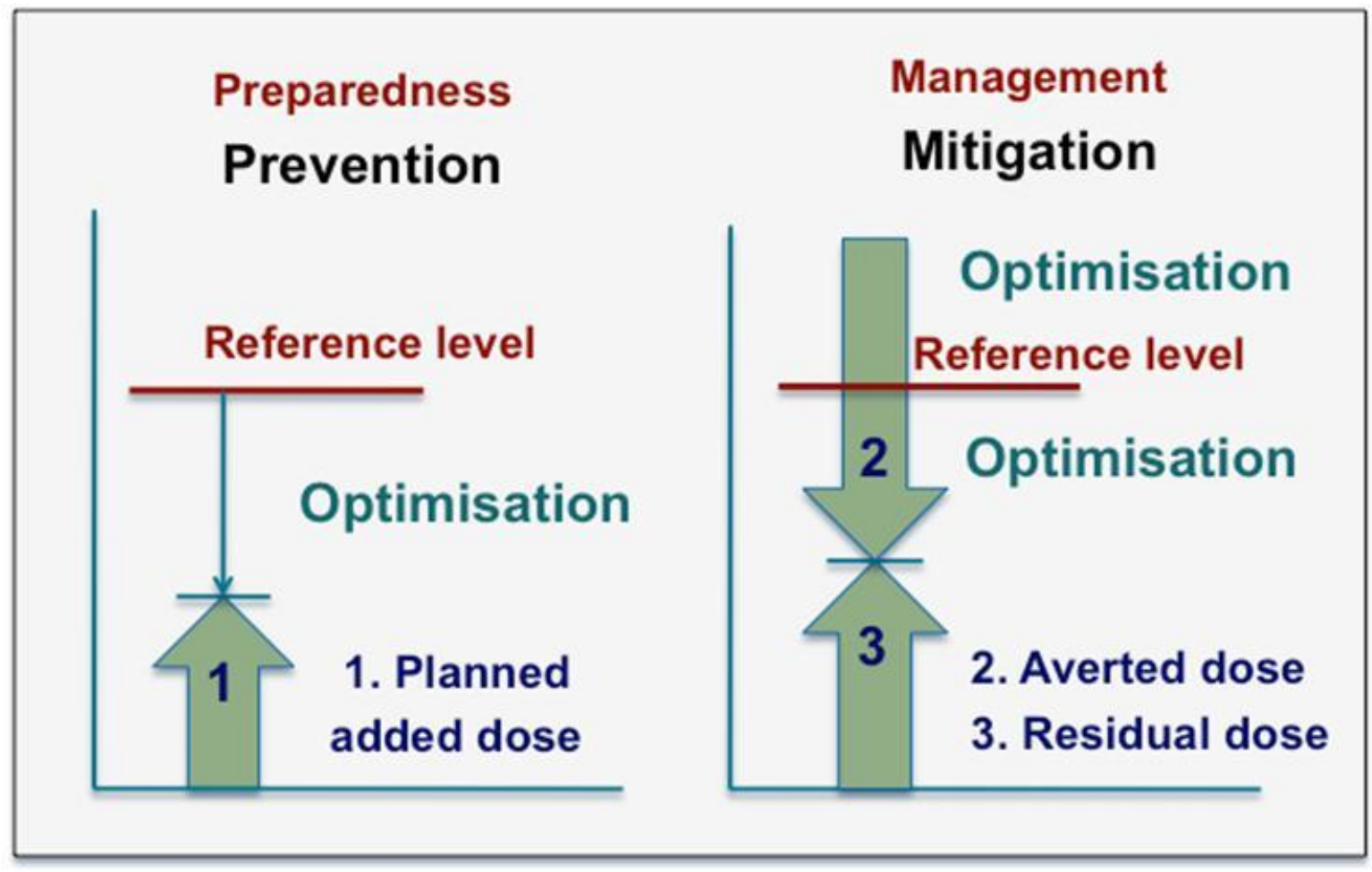

The implementation of the optimization principle in emergency and existing exposure situations

The program of work of Committee 4 in 2010 is described below.

Task Group 71 on the Protection of the Public and Workers in the Use of lonizing Radiation in Screening Activities Applied to Persons and Cargo for Security Purposes

\section{Chair: Donald A. Cool}

Established by the Main Commission in Suzhou in 2010, the Task Group is building on the results of a former Working Party which reviewed the topic for several years. Its 
objective is to examine how the radiation protection principles recommended by ICRP should be interpreted and applied within the context of security screening. In particular the Task Group will discuss how the principles for planned exposure situations, including optimization with the use of constraints and the concept of limitation apply within a security screening context. The Task Group will also examine the application of the Commission's recommendations to groups of individuals who may be exposed as a consequence of cargo screening. These groups may include the occupationally exposed individuals in set up for use start, operation and maintenance of the screening equipment, individuals such as drivers, who have been permitted in the cab of the vehicle, and other individuals who may unintentionally be exposed as a "stow-away" in a cargo container. The report should be published in 2012.

Task Group 76 on the Application of the Commission's Recommendations to NORM (Naturally Occurring Radioactive Materials)

\section{Chair: Peter Burns}

Established by the Main Commission in Berlin in 2007, the Task Group has been relaunched in Porto in 2009 with a refined objective and a new membership. Its objective

is to develop a framework for the practical application of the Commission's recommendations, in particular the optimisation principle, for the protection of workers, the public and the environment in cases of exposure arising from Naturally Occurring Radioactive Material (NORM). Taking into account publications and documents of other international organisations, the Task Group report will cover the entire range of activities associated with the processing, production or use of bulk materials with enhanced levels of naturally occurring radionuclides, as well as the presence of such materials in consumer products, particularly in construction materials. The application of such a framework should also be illustrated to a few relevant activities that are currently a concern (oil, coal, rare earths, and phosphate). The report should be published in 2012.

Task Group 80 on the Application of the Commission's Recommendations to the Geological Disposal of Long-lived Solid Radioactive Waste

\section{Chair: Wolfgang Weiss}

This Task Group was established by the Main Commission Porto in November 2009. Its objective is to prepare a publication that describes in plain language and clarifies the application of the new recommendations for the protection against occupational and public exposures that may result from the geological disposal of long-lived solid radioactive waste. Taking into account previous ICRP recommendations (ICRP Publications 77 and 81 ) and relevant materials from international organisations, the publication will discuss how the key radiological protection principles for planned exposure situation apply to the successive phases of managing such type of disposal of 
long-lived solid radioactive waste. It will also address the transition from a planned to an existing exposure situation in cases of loss of control as well as the applicability of estimated individual and collective effective doses as a means for making decisions about the different time scales in the lifetime of a repository. The report should be published in 2011.

Task Group 81 on the Application of the Commission's Recommendations to Radon Exposure

\section{Chair: Jean-François Lecomte}

In Porto, the Commission established this Task Group on radon exposure. The objective is to prepare a publication that describes and clarifies the application of the new recommendations (ICRP Publication 103) for the protection of the public and workers (notably workers in uranium mines and other mines) against radon and thoron exposures in dwellings, workplaces and other locations. The publication will discuss in which cases exposure to radon is either a planned exposure situation or an existing exposure situation with the relevant application of the radiological protection principles, as well as the dosimetric reference and rationale. The publication will also address the setting of reference levels and dose constraints. The publication will build on the previous ICRP Publications 65, 101 and 103, the joint C1-C2-C4 report on assessment and control of lung cancer risk from radon and the November 2009 Commission's Statement on radon as well as experience from many countries and organisations. The report should be published in 2011.

\section{Task Group 83 on the Protection of Aircraft Crew against Cosmic radiation} Exposure

\section{Chair: Jacques Lochard}

This Task Group was proposed by the Main Commission in Porto in 2009 and its Terms of Reference approved in Cape Town in 2010. Its objective is to prepare a publication that describes and clarifies the application of the new recommendations (ICRP Publication 103) for the protection of aircrews against cosmic rays. The publication will discuss the type of exposure situations relevant to control aircrew exposures and the appropriate radiation protection principles to be implemented. Particular attention will be given to the practical implementation of the optimization principle with the associated reference levels. The final report is expected in 2012. 
Working Party on the Concept of Radiation Risk within the System of Radiological Protection

\section{Chair: Jacques Lochard}

This Working Party was created in Porto in November 2009. Its objective is to review the use of the concept of radiation risk in the evolution of the radiological protection system. It also will review the related concepts such as detriment and effective dose and clarify the issue of having a prospective view for risk comparison, the influence of uncertainty of risk as well as the attributability and plausibility of risk. 


\section{Committee 5 (Protection of the Environment)}

Committee 5 is concerned with radiological protection of the environment. It will aim to ensure that the development and application of approaches to environmental protection are compatible with those for radiological protection of man, and with those for protection of the environment from other potential hazards.

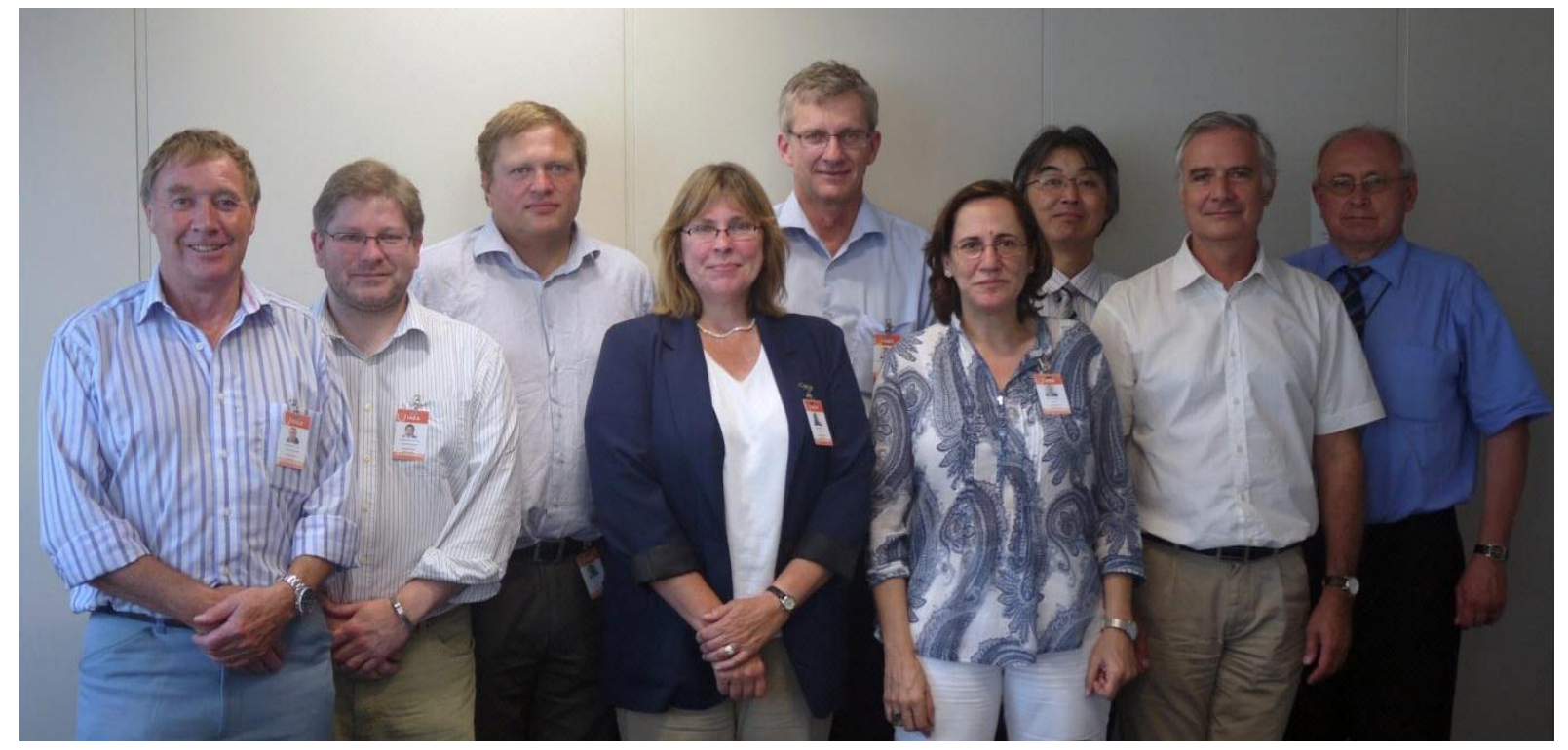

ICRP Committee 5 in Vienna, Austria, August 2010

Following the publication of its major document on Reference Animals and Plants (ICRP Publication 108), Committee 5 continues to consider how this basic information can best be applied to different exposure situations, and is developing the additional databases necessary to do so. It is also looking at how the Commission's advice might best be used to satisfy a wide range of environmental protection requirements arising from regional or national legislation. The science base relating to environmental protection is also being further reviewed, particularly with regard to radiation weighting factors, and to the utility of more realistic dosimetry for some biotic types.

Task Group 73 on Environmental Protection: Transfer Parameters for Reference Animals and Plants

\section{Chair: Per Strand}

To estimate exposure of Reference Animals and Plants to ionising radiation models are usually required simulating the behaviour of radionuclides in the environment. This Task Group has reviewed existing databases with regard to a wide range of transfer parameters to estimate the internal and external exposure of the Reference 
Animals and Plants. The final report describes the formulation of a database which has allowed the collation of data on whole body Concentration Ratios. For use with the Reference Animals and Plants, emphasis has been placed on collating data from field studies, although data from laboratory experiments have also been included. The database is structured in terms of generic wildlife groups, but the data have also been attributed to the Reference Animals and Plants wherever possible. In this way Concentration Ratios specifically for the Reference Animals and Plants were extracted and, in cases where transfer data were lacking, a data-gap filling methodology has been used to derive suitable surrogate values. Statistical summaries of the datasets are provided and Concentration Ratio values for 39 element and 12 Reference Animal and Plant combinations have been reported. The data coverage, reliance on derived values and applicability of this approach for each of the Reference Animals and Plants is discussed.

\section{Task Group 69 on Improved Dosimetry for Reference Animals and Plants}

\section{Chair: Gerhard Pröhl}

This Task Group is examining improved dosimetric models for application to larger Reference Animals and Plants, including the use of voxel phantoms for organisms greater than $1 \mathrm{~kg}$. A final report is likely to be available for public consultation in 2011.

\section{Task Group 72 on RBE and Reference Animals and Plants}

\section{Chair: Kathryn Higley}

This Task Group is reviewing the data bases with regard to RBE and the Reference Animals and Plants, and is examining the potential for the use of radiation weighting factors to apply to the vertebrate members of the set. A very large data base has been reviewed and the task is continuing. An initial report is expected at the end of 2011.

Joint C5/C4 Task Group 82 on the Application of the ICRP's Approach to Environmental Protection under Different Exposure Situations

\section{Chair: R Jan Pentreath}

Although ICRP Publication 103 had introduced a new 'environmental protection' requirement into its Recommendations (following on from ICRP Publication 91), the subsequent publication of ICRP Publication 108 has now made it necessary to demonstrate, explicitly, how the expanded ICRP framework collectively fits together in a coherent way. This joint Task Group has produced a draft report which is still under discussion. It considers how the subject of protection of the environment fits within the Commission's overall framework of Justification, Optimisation of protection, and the 
application of Dose Limits, and how best to apply it to all three exposure situations via the derivation of Environmental Reference Levels. Further meetings of the TG will take place during 2011 and a draft report will be considered by the MC in October 2011 prior to it being submitted for public consultation. 


\section{ICRP Publications in 2010}

ICRP released three reports in 2010, two in the Annals of the ICRP, and one joint ICRU/ICRP report in the Journal of the ICRU:

- ICRP Publication 111: Application of the Commission's Recommendations to the Protection of People Living in Long-term Contaminated Areas after a Nuclear Accident or a Radiation Emergency

- ICRP Publication 112: Preventing Accidental Exposures from New External Beam Radiation Therapy Technologies

- ICRU Report 84 (prepared jointly with ICRP): Reference Data for the Validation of Doses from Cosmic Radiation Exposure of Aircraft Crew

In addition, permission was granted for organisations to prepare and distribute translations of ICRP publications in various languages. For example, ICRP Publication 103, The 2007 Recommendations of the International Commission on Radiological Protection, is now available for free download from the ICRP web site in many languages e.g. Chinese, French, German, Italian, Korean, Romanian, Russian, and Spanish. Translation of this publication into other languages is on-going, as is translation of other ICRP publications. Translated publications are generally made available for free download through the ICRP web site.

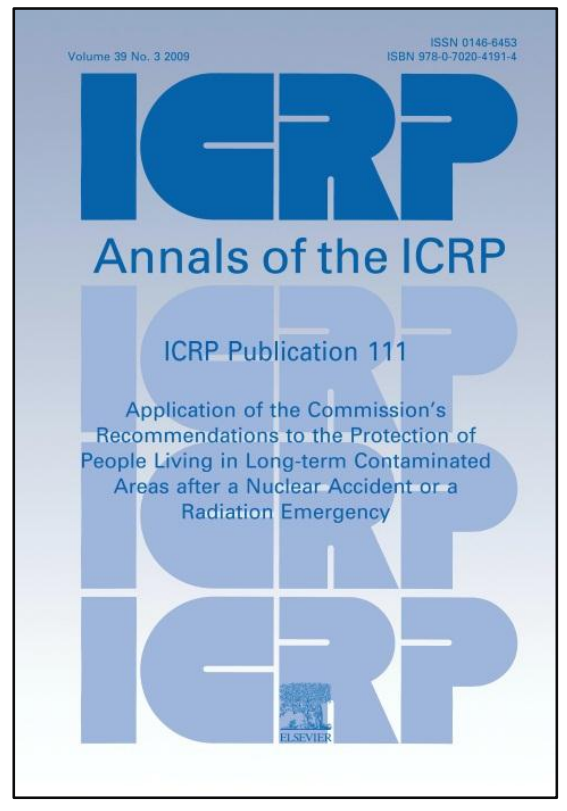

ICRP Publication 111: Application of the Commission's Recommendations to the Protection of People Living in Long-term Contaminated Areas after a Nuclear Accident or a Radiation Emergency

\section{J. Lochard, I. Bogdevitch, E. Gallego, P. Hedemann-} Jensen, A. McEwan, A. Nisbet, A. Oudiz, T. Schneider, P. Strand, Z. Carr, A. Janssens, T. Lazo

In this report, the Commission provides guidance for the protection of people living in long-term contaminated areas resulting from either a nuclear accident or a radiation emergency. The report considers the effects of such events on the affected population. This includes the pathways of human exposure, the types of exposed populations, and the characteristics of exposures. Although the focus is on radiation protection considerations, the report also recognises the complexity of post-accident situations, which cannot be managed without addressing all 
the affected domains of daily life, i.e. environmental, health, economic, social, psychological, cultural, ethical, political, etc. The report explains how the 2007 Recommendations apply to this type of existing exposure situation, including consideration of the justification and optimisation of protection strategies, and the introduction and application of a reference level to drive the optimisation process. The report also considers practical aspects of the implementation of protection strategies, both by authorities and the affected population. It emphasises the effectiveness of directly involving the affected population and local professionals in the management of the situation, and the responsibility of authorities at both national and local levels to create the conditions and provide the means favouring the involvement and empowerment of the population. The role of radiation monitoring, health surveillance and the management of contaminated foodstuffs and other commodities are described in this perspective. The Annex summarises past experience of long term contaminated areas resulting from radiation emergencies and nuclear accidents, including radiological criteria followed in carrying out remediation measures.

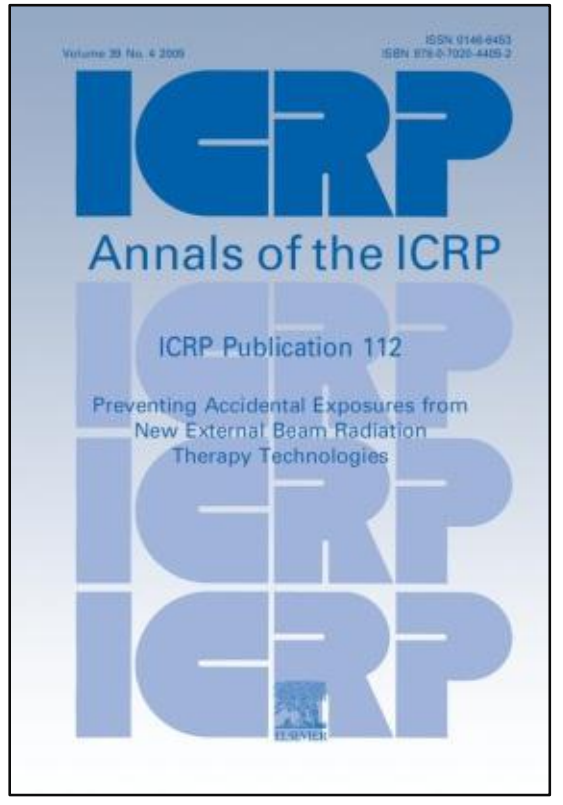

\section{ICRP Publication 112: Preventing Accidental Exposures from New External Beam Radiation Therapy Technologies}

\section{P. Ortiz Lopez, J.-M. Cosset, P. Dunscombe, O. Holmberg, J.-C. Rosenwald, L. Pinillos Ashton, J.J. Vilaragut Llanes, S. Vatnitsky}

Disseminating the knowledge and lessons learned from accidental exposures is crucial in preventing reoccurrence. This is particularly important in radiation therapy; the only application of radiation in which very high radiation doses are deliberately given to patients to achieve cure or palliation of disease.

Lessons from accidental exposures are, therefore, an invaluable resource for revealing vulnerable aspects of the practice of radiotherapy, and for providing guidance for the prevention of future occurrences. These lessons have successfully been applied to avoid catastrophic events with conventional technologies and techniques. Recommendations, for example, include the independent verification of beam calibration and independent calculation of the treatment times and monitor units for external beam radiotherapy, and the monitoring of patients and their clothes immediately after brachytherapy. 
New technologies are meant to bring substantial improvement to radiation therapy. However, this is often achieved with a considerable increase in complexity, which in turn brings opportunities for new types of human error and problems with equipment. Dissemination of information on these errors or mistakes as soon as it becomes available is crucial in radiation therapy with new technologies. In addition, information on circumstances that almost resulted in serious consequences (near misses) is also important, as the same type of events may occur elsewhere. Sharing information about near-misses is thus a complementary important aspect of prevention. Lessons from retrospective information are provided in Sections 2 and 4 of this report.

Disseminating lessons learned for serious incidents is necessary but not sufficient when dealing with new technologies. It is of utmost importance to be proactive and continually strive to answer questions such as 'What else can go wrong', 'How likely is it?' and 'What kind of cost-effective choices do I have for prevention?'. These questions are addressed in Sections 3 and 5 of this report.

Section 6 contains the conclusions and recommendations. This report is expected to be a valuable resource for radiation oncologists, hospital administrators, medical physicists, technologists, dosimetrists, maintenance engineers, radiation safety specialists, and regulators. While the report applies specifically to new external beam therapies, the general principles for prevention are applicable to the broad range of radiotherapy practices where mistakes could result in serious consequences for the patient and practitioner.

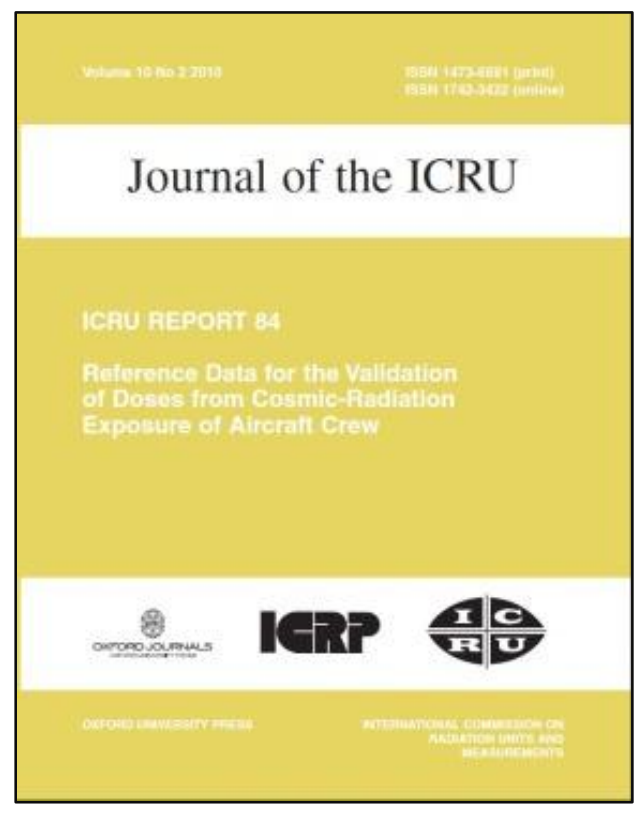

ICRU Report 84 (prepared jointly with ICRP): Reference Data for the Validation of Doses from Cosmic Radiation Exposure of Aircraft Crew

\section{Bartlett, H.-G. Menzel, P. Beck, P. Goldhagen, B. Lewis, L. Lindborg, K. O'Brien, H. Schraube, F. Wissmann}

Aircraft crews are exposed to elevated levels of cosmic radiation of galactic and solar origins and secondary radiations produced in the atmosphere, the aircraft, and its contents. The ICRP has recommended that exposures of aircraft crew to cosmic radiation in the operation of commercial jet aircraft be included as occupational exposure. The radiation field inside an aircraft is to a large extent uniform, and doses are generally predictable, with the exception of rare, intense, high energy solar-particle 
events. Events comparable to unplanned exposure in other radiation workplaces cannot normally occur. The routine assessment of annual doses of aircraft crew is based on calculated values of effective dose rate in conjunction with staff roster information. In routine radiation protection, traceable measurements are the basis of the overall system of dose assessment, and it is generally accepted that methods of annual dose assessment for aircraft crew based on radiation transport calculations of effective dose rates should be periodically verified by measurement. The purpose of this Report is to provide reference data derived from measurements against which the results of routine methods of assessing annual doses using calculations can be compared (benchmarked) for validation purposes. The reference values of ambient dose equivalent rate for exposure to cosmic radiation of galactic origins in aircraft at aviation altitudes cover the range of geomagnetic latitudes of relevance, for three different time periods within the most recently completed solar cycle 23 . The relationships between ambient dose equivalent and effective dose are given, allowing the calculation of effective dose from values of ambient dose equivalent. These reference values should facilitate international harmonization of dose assessments for aircraft crew in terms of effective dose. 


\section{Obtaining ICRP Publications}

An index to all ICRP publications can be found at www.icrp.org.

ICRP publications are available from reputable booksellers or directly from the Commission's publishers, Elsevier Science:

Web sites: $\quad$ www.elsevier.com www.sciencedirect.com/science/journal/00742740

(for ICRP Publication 23 and earlier) www.sciencedirect.com/science/journal/01466453

(for ICRP Publication 24 and later) www.icrp.info

Questions to Elsevier Science regarding print subscriptions should be directed to:

\section{Americas}

Journals Customer Service

Tel: (877) 839-7126 (Toll Free US \& Canada)

Tel: (314) 453-7041 (Outside US \& Canada)

Fax: (314) 453-5170

E-mail: JournalsOnlineSupport-usa@elsevier.com

\section{Europe, Africa, Middle East}

Customer Service Department

PO Box 211

1000 AE Amsterdam

The Netherlands

Tel: +31 20-485-3757

Fax: +31 20-485-3432

E-mail: JournalsCustomerServiceEMEA@elsevier.com

\section{Asia and Australia}

Customer Service Department

Winsland House I

3 Killiney Road \#08-01

Singapore 239519

Tel: +65 6349-0222

Fax: +65 6733-1510

E-mail: JournalsCustomerServiceAPAC@elsevier.com 


\author{
Japan \\ Customer Service Department \\ 4F Higashi Azabu, 1 Chome Bldg \\ 1-9-15 Higashi Azabu, Minato-ku \\ Tokyo 106-0044, Japan \\ Tel: +81 355615037 \\ Fax: +81 355615047 \\ E-mail: JournalsCustomerServiceJapan@elsevier.com
}




\section{ICRP Membership as of December 31, 2010}

\section{Main Commission}

Claire Cousins (Chair)

Abel J González (Vice-chair)

John D Boice Jr

John Cooper

Jai-Ki Lee

Jacques Lochard (C4 Chair)

Hans G Menzel (C2 Chair)

Ohtsura Niwa

Emeritus Members

Roger H Clarke

Bosse Lindell

Charles B Meinhold

\section{Scientific Secretariat}

Christopher H Clement (Scientific Secretary)

Committee 1 (Radiation Effects)

\section{R Julian Preston (Chair)}

William Morgan (Vice-chair)

Jolyon Hendry (Secretary)

Tamara Azizova

Ranajit Chakraborty

Sarah Darby

Nori Nakamura

Werner Rühm
Zi Qiang Pan

$R$ Jan Pentreath (C5 Chair)

R Julian Preston (C1 Chair)

Natalia Shandala

Eliseo Vañó (C3 Chair)

Christopher H Clement

(Scientific Secretary)

Fred A Mettler

Warren K Sinclair

Christian Streffer

Lynn Lemaire (Executive Assistant)

Sisko Salomaa

Alice Sigurdson

Fiona Stewart

Dan Stram

Margot Tirmarche

Richard Wakeford

Ping-Kun Zhou

Committee 2 (Doses from Radiation Exposures)

\section{Hans G Menzel (Chair)}

John Harrison (Vice-chair and Secretary)

Michael Bailey

Mikhail Balonov

David Bartlett

Vladimir Berkovski

Wesley Bolch

Roger Cox

Günther Dietze
Keith Eckerman

Akira Endo

Nobuhito Ishigure

Richard Leggett

Joyce Lipsztein

Jizeng $\mathrm{Ma}$

Francois Paquet

Nina Petoussi-Hen $\beta$

Ambika Sahai Pradhan 


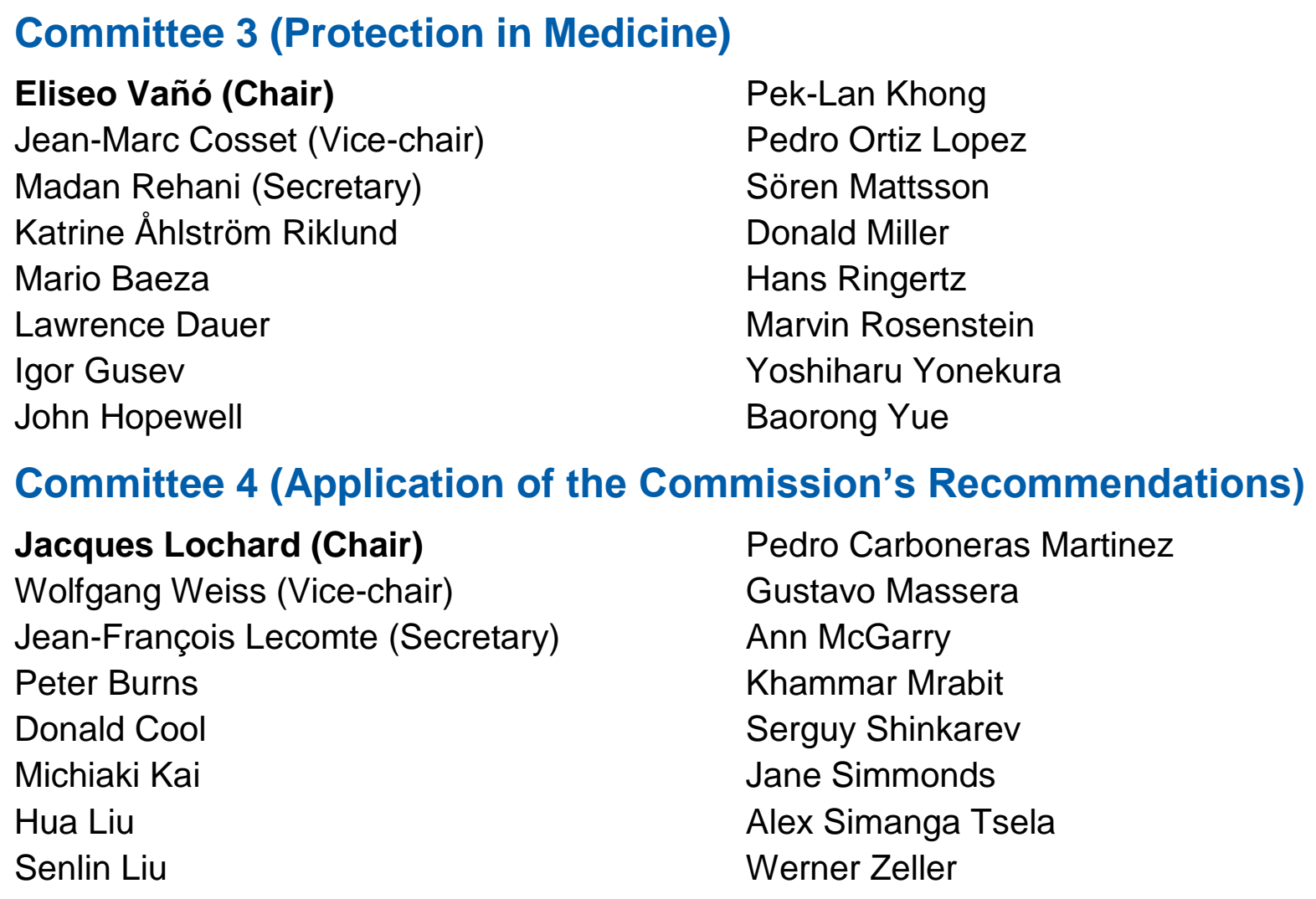

Sigurður Magnússon

Committee 5 (Protection of the Environment)

$R$ Jan Pentreath (Chair)

Carl-Magnus Larsson (Vice-chair)

Almudena Real (Secretary)

Francois Bréchignac

David Copplestone
Kathryn Higley

Gerhard Pröhl

Kazuo Sakai

Per Strand 


\section{Summary Financial Information 2006-2010}

\begin{tabular}{|c|c|c|c|c|c|}
\hline ITEM & 2010 & 2009 & 2008 & 2007 & 2006 \\
\hline \multicolumn{6}{|l|}{ INCOME STATEMENT } \\
\hline \multicolumn{6}{|l|}{ Incoming Resources } \\
\hline Grants Received & 617168 & 418408 & 412100 & 472703 & 231592 \\
\hline Royalties & 107551 & 107231 & 84596 & 112589 & 127176 \\
\hline Interest & 0 & 1138 & 5935 & 14996 & 15862 \\
\hline Other Income & 0 & 2109 & 1516 & 925 & 1044 \\
\hline Total Incoming Resources & 724719 & 528886 & 504147 & 601213 & 375674 \\
\hline \multicolumn{6}{|l|}{ Resources Expended } \\
\hline Promotion of Radiological Protection & 552953 & 532464 & 326444 & 386541 & 361434 \\
\hline Governance Costs & 169027 & 133095 & 140175 & 152942 & 145498 \\
\hline Other Resources Expended & 2752 & (22 834) & 33418 & $(13079)$ & (35 396) \\
\hline Total Resources Expended & 724732 & 642725 & 500037 & 526404 & 471536 \\
\hline Net Movement in Resources & $(13)$ & $(113839)$ & 4110 & 74809 & (95 862) \\
\hline Total Funds Carried Forward & 390140 & 390153 & 503922 & 499882 & 425073 \\
\hline \multicolumn{6}{|l|}{ "BALANCE SHEET } \\
\hline Tangible Fixed Assets & 4329 & 5977 & 3109 & 1516 & 2895 \\
\hline Current Assets & 391445 & 400563 & 529296 & 511375 & 439223 \\
\hline Debtors (falling due within one year) * & 168413 & 0 & 0 & 0 & 0 \\
\hline Creditors (falling due within the year) ${ }^{\dagger}$ & $(174$ 047) & $(16387)$ & $(28413)$ & $(13009)$ & $(17045)$ \\
\hline Net Assets & 390140 & 390153 & 503992 & 499882 & 425073 \\
\hline
\end{tabular}

This is a summary of ICRP annual financial statements as audited by Tudor John Chartered Accountants, Epsom, UK. All amounts are expressed in US dollars.

* The accounting policy of ICRP with respect to grants received is to recognise the income when the charity is legally entitled to the income and the amount can be quantified with reasonable accuracy. Generally this has led to only recognising grants received on a cash basis. As at December 31, 2010, ICRP had a firm commitment from the EC to pay the balance of funds owed in respect of work concluded in December 2009. On February 3, 2011 the sum of $\$ 125,185$ was received and accordingly this amount is included in debtors for 2010. The balance of the debtors relate to annual grants from regular donors where the amounts have been received after December 31, 2010.

${ }^{\dagger}$ Creditors of $\$ 174,047$ in 2010 include $\$ 150,000$ of deferred revenue in connection with the 2011 meeting and symposium. Although the funds were received in 2010 , the revenue has been deferred so the grant will be recognised in 2011 to match the revenue with the relevant costs. 


\section{Organisations Providing Grants to ICRP in 2010}

Commission of European Communities

International Atomic Energy Agency

International Radiation Protection Association

International Society of Radiology

Organisation of Economic Cooperation and Development: Nuclear Energy Agency

Australia: Australian Radiation Protection and Nuclear Safety Agency

Argentina: Autoridad Regulatoria Nuclear de Argentina

Canada: Canadian Nuclear Safety Commission \& Health Canada

China: Chinese Society of Radiation Protection

Denmark: Statens Institut for Strålehygiejne

Finland: Säteilyturvakeskus

France: Institut de Protection et de Sûreté Nucléaire

Germany: Bundesministerium für Umwelt, Naturschutz und Reaktorsicherheit

Iceland: Geislavarnir Rikisins

Japan: Japan Atomic Energy Agency

Norway: Statens strålevern

Russia: Burnasyan Federal Medical Biohysical Center, Federal Medical Biological Agency

South Korea: Korea Nuclear International Cooperation Foundation

Spain: Consejo de Seguridad Nuclear

Sweden: Miljödepartementet

USA: Nuclear Regulatory Commission \& Environmental Protection Agency 


\section{Contact Information}

Christopher Clement, ICRP Scientific Secretary and Editor of the Annals of the ICRP, can be contacted at:

International Commission on Radiological Protection

PO Box 1046, Station B

280 Slater Street

Ottawa, Ontario K1P 5 S9

CANADA

Telephone: +1 (613) 944-1918

Fax: $\quad+1$ (613) $944-1920$

E-mail: $\quad$ sci.sec@icrp.org

Web site: www.icrp.org

Executive Assistant: Lynn Lemaire

Telephone: $\quad+1$ (613) $947-9750$

E-mail:

admin@icrp.org 